\section{Serum $\alpha$-Fetoprotein Levels Predict Early Virologic Response in HIV-Positive Subjects Treated for Chronic Hepatitis C}

\section{To the Editor:}

Serum $\alpha$-fetoprotein (AFP) is a fetal glycoprotein produced by the yolk sac and fetal liver ${ }^{1}$ that is routinely used as a marker of hepatocellular carcinoma in subjects with chronic liver diseases. ${ }^{2,3}$ Elevations of AFP levels may be often observed in acute and chronic viral hepatitis also ${ }^{4,5}$ and are usually associated with hepatic cirrhosis. ${ }^{5,6}$ These elevations have been correlated to hepatic damage per se with selective transcriptional activation of the AFP gene. ${ }^{7}$ Recently, it has been demonstrated that elevated AFP levels correlate with a low probability of sustained virologic response (SVR) to chronic hepatitis $\mathrm{C}$ treatment, at least in patients with hepatitis $\mathrm{C}$ virus (HCV) genotype $4 .^{8}$ To date, no study has evaluated the association between serum AFP levels and early virologic response (EVR) to anti-HCV treatment in the HIV-positive population.

In this study we evaluated 33 consecutive HIV/HCV-coinfected subjects followed up at our clinic who initiated an anti-HCV treatment, from January 2006 , with pegylated interferon $\alpha-2 \mathrm{a}$ (at a dosage of $180 \mu \mathrm{g} /$ weekly) plus ribavirin (at a dosage of 1000 to $1200 \mathrm{mg}$ according to body weight) to treat HCV infection. The aim of the present analysis is to define the predictive role of AFP on EVR and on rapid virologic response (RVR) to anti-HCV treatment, which are both strong predictors of SVR..$^{910}$ The following variables were collected at baseline (time of starting anti-HCV treatment): gender, age, race, body mass index (BMI), platelet count, aspartate aminotransferase (AST), alanine aminotransferase (ALT), AFP, CD4 cell counts, HIV RNA, HCV RNA, HCV genotype, and use of highly active antiretroviral therapy (defined as use of $\geq 2$ nucleoside reverse transcriptase inhibitors with any protease inhibitors or nonnucleoside reverse transcriptase inhibitors). Exclusion criteria were any other cause of liver disease (such as hepatitis B infection), alcohol consumption $>50 \mathrm{~g} /$ day for men and $>40$ $\mathrm{g} /$ day for women, and contraindications to initiation of pegylated interferon or ribavirin treatment (psychiatric disorders, anemia, cardiovascular diseases, diabetes, or autoimmune diseases). Normal values of AFP were considered those $<4.6 \mathrm{IU} / \mathrm{mL}$. HIV RNA load was assessed using a reverse transcriptase polymerase chain reaction (RT-PCR) assay with a detection limit of $<60$ copies $/ \mathrm{mL}$ (Qiagen, Heiden, Germany). Serum HCV RNA was evaluated by nested PCR (Amplicor; Roche, Basel, Switzerland; detection limit $<15$ IU/L). HCV genotyping was performed using a line-probe assay (INNO-LiPA HCV II; Immunogenetics, Antwerp, Belgium). Liver fibrosis at baseline was evaluated using the FIB-4 index, which has been validated in the HIV population. ${ }^{11}$ The index is based on this simple equation: age ([years] $\times$ AST $[\mathrm{IU} / \mathrm{L}]) /\left(\right.$ platelets $\left.\left[10^{9} / \mathrm{L}\right]\right) \times(\text { ALT }[\mathrm{IU} / \mathrm{L}])^{1 / 2}$. FIB-4 values $>3.25$ were those considered associated with advanced fibrosis. EVR was defined as HCV RNA $<15$ $\mathrm{IU} / \mathrm{mL}$ after 3 months of anti-HCV treatment; RVR was defined as HCV RNA $<15$ IU/L after 1 month of antiHCV treatment. Differences between variables were calculated using the $\chi^{2}$ and the Student $t$ tests when appropriate.

Table 1 shows the demographics and clinical characteristics of the subjects included in our study, grouped according to the AFP values at baseline. All patients were white. Seventeen subjects (51.5\%) had AFP $\leq 4.6 \mathrm{IU} / \mathrm{mL}$, and 16 $(48.5 \%)$ had values $>4.6 \mathrm{IU} / \mathrm{mL}$. No statistically significant differences were observed in the 2 groups at baseline according to the variables considered. AFP $>4.6 \mathrm{IU} / \mathrm{mL}$ was associated with advanced liver fibrosis; in particular, FIB- 4 values $>3.25$ were observed in 4 of $17(23.5 \%)$ subjects with AFP $\leq 4.6$ $\mathrm{IU} / \mathrm{mL}$ and in 8 of $16(50 \%)$ of those with AFP levels $>4.6 \mathrm{IU} / \mathrm{mL}(P=0.01)$. After 3 months of anti-HCV treatment, median AST and ALT levels decreased in both groups. In subjects with AFP $\leq 4.6 \mathrm{IU} /$ $\mathrm{mL}$, median AST and ALT decreased from
$101 \mathrm{IU} / \mathrm{L}$ (interquartile range [IQR]: 89 to 115 ) to $37 \mathrm{IU} / \mathrm{L}$ (IQR: 30 to 43 ; $P<0.01$ ) and from $93 \mathrm{IU} / \mathrm{L}$ (IQR: 63 to 101 ) to $35 \mathrm{IU} / \mathrm{L}$ (IQR: 29 to 46 ; $P<0.01$ ), whereas in subjects with AFP $>4.6 \mathrm{IU} / \mathrm{mL}$ median AST and ALT decreased from 116 IU/L(IQR: 99 to 188 ) to 54 IU/L (IQR: 33 to $68 ; P<0.01$ ) and from $104 \mathrm{IU} / \mathrm{L}$ (IQR: 76 to 124 ) to $52 \mathrm{IU} / \mathrm{L}$ (IQR: 31 to $63 ; P<0.01$ ), respectively. RVR was achieved in 8 of 17 subjects $(47.1 \%)$ with AFP $\leq 4.6 \mathrm{IU} /$ $\mathrm{mL}$ and in 3 of $16(18.8 \%)$ with AFP $>4.6 \mathrm{IU} / \mathrm{mL}$ at baseline $(P<0.01)$; EVR was observed in 13 of 17 subjects (76.5\%) with AFP $\leq 4.6 \mathrm{IU} / \mathrm{mL}$ and in 5 of $16(31.3 \%)$ with AFP $>4.6 \mathrm{IU} / \mathrm{mL}$ at baseline $(P<0.001)$. Among the 4 subjects with AFP $\leq 4.6 \mathrm{IU} / \mathrm{mL}$ who did not achieve EVR, 2 had genotype 1, 1 had genotype $3 \mathrm{a}$, and 1 had genotype $4 \mathrm{c} /$ 4d. EVR was not reached by 11 subjects with AFP $>4.6 \mathrm{IU} / \mathrm{mL}$; among these, 5 had genotype 1, 4 had genotype 3a, and 2 had genotype $4 \mathrm{c} / 4 \mathrm{~d}$.

To our knowledge, this is the first study demonstrating that elevated serum levels of AFP may be predictive of poor rapid and early virologic response to anti-HCV treatment in the HIVinfected population. Our study, which included subjects with different HCVgenotypes, confirmed the results of Males et $\mathrm{al}^{8}{ }^{8}$ who described the correlation between higher AFP levels and virologic response to anti-HCV treatment in HCV-infected subjects with genotype 4 . In our study, the only factor associated with an elevated AFP level was advanced liver fibrosis, evaluated with the FIB-4 index because liver biopsy was not systematically performed in our cohort. ${ }^{11}$ We confirmed that recently published findings that describe a correlation between elevated AFP levels and liver fibrosis in HCV-infected, HIV-negative subjects also apply to the HIV-infected population. ${ }^{8,12}$

The identification of biochemical markers that may predict early virologic response to anti-HCV treatment is a very important tool for the correct management of the condition. Our findings suggest that pretreatment levels of AFP should be included in the routine assessment of factors potentially predictive of the anti-HCV treatment outcome. A 
TABLE 1. Demographics and Clinical Characteristics of the 33 HIV/HCV-Coinfected Subjects, Grouped According to Their Serum $\alpha$-Fetoprotein (AFP) Values at Baseline

\begin{tabular}{|c|c|c|c|}
\hline & AFP $\leq 4.6(n=17)$ & AFP $>4.6(n=16)$ & Total $(\mathrm{N}=33)$ \\
\hline Males (\%) & $13(76.5)$ & $13(81.2)$ & $26(78.8)$ \\
\hline Median age, y (IQR) & $42(39$ to 46$)$ & $43(40$ to 46$)$ & $43(39$ to 46$)$ \\
\hline $\mathrm{BMI}, \mathrm{kg} / \mathrm{m}^{2}$ (IQR) & $22.7(21.5$ to 24.2$)$ & $23.2(22.5$ to 27.0$)$ & $23.1(22.3$ to 27.0$)$ \\
\hline $\mathrm{CD} 4$, cells $/ \mathrm{mm}^{3}$ (IQR) & $450(352$ to 570$)$ & $416(362$ to 462$)$ & $428(356$ to 546$)$ \\
\hline HIV RNA $<60$ copies/mL ( $\%)$ & $12(70.6)$ & $13(81.2)$ & $25(75.7)$ \\
\hline Use of HAART $(\%)$ & $14(82.3)$ & $12(75)$ & $26(78.8)$ \\
\hline Median HCV RNA $\log 10$ copies/mL (IQR) & $5.79(5.53$ to 6.27$)$ & $5.87(5.80$ to 5.94$)$ & $5.84(5.53$ to 6.27$)$ \\
\hline Median AST, IU/L (IQR) & $101(89$ to 115$)$ & $116(99$ to 188$)$ & $106(92$ to 139$)$ \\
\hline Median ALT, IU/L (IQR) & $93(63$ to 101$)$ & 104 (76 to 124$)$ & $97(69$ to 109$)$ \\
\hline Platelets, cells $/ \mathrm{mm}^{3}$ (IQR) & $214(151$ to 228$)$ & $179(128$ to 230$)$ & $197(129$ to 230$)$ \\
\hline Median total cholesterol, mg/dL (IQR) & 179 (161 to 194$)$ & $152(139$ to 173$)$ & $173(141$ to 188$)$ \\
\hline Median triglycerides, mg/dL (IQR) & $150(117$ to 202$)$ & $132(96$ to 172$)$ & $147(104$ to 193$)$ \\
\hline Median FIB-4 (IQR) & $2.06(1.54$ to 3.23$)$ & $3.13(2.50$ to 5.21$)$ & $2.46(1.61$ to 3.89$)$ \\
\hline Genotype $1(\%)$ & $7(41.2)$ & $6(37.5)$ & $13(39.4)$ \\
\hline Genotype $3(\%)$ & $7(41.2)$ & $7(43.7)$ & $14(42.4)$ \\
\hline Genotype $4(\%)$ & $3(17.6)$ & $3(18.7)$ & $6(18.2)$ \\
\hline
\end{tabular}

prolonged follow-up is required to confirm the predictive role of AFP levels at baseline in determining sustained virologic response to anti-HCV treatment.

Marco Bongiovanni, MD
Roberto Ranieri, MD
Camilla Tincati, MD
Maddalena Casana, MD
Giulia Marchetti, MD
Antonella d'Arminio Monforte, MD
Clinic of Infectious Diseases
San Paolo Hospital
University of Milan, Italy

\section{REFERENCES}

1. Halbrecht I, Klibanski C. Identification of a new normal embryonic haemoglobin. Nature. 1956;178:794-795.

2. Sato Y, Nakata K, Kato Y, et al. Early recognition of hepatocellular carcinoma based on altered profiles of alpha-fetoprotein. $N E n g l$ J Med. 1993;328:1802-1806.

3. Gebo KA, Chander G, Jenckes MW, et al. Screening tests for hepatocellular carcinoma in patients with chronic hepatitis $\mathrm{C}$ : a systematic review. Hepatology. 2002;36(Suppl 1):S84-S92.

4. Hu KQ, Kyulo NL, Lim N, et al. Clinical significance of increased alpha-fetoprotein (AFP) in patients with chronic hepatitis $\mathrm{C}$, but not hepatocellular carcinoma. Am J Gastroenterol. 2004;99:860-865.

5. Bayati N, Silverman AL, Gordon SC. Serum alpha-fetoprotein levels and liver histology in patients with chronic hepatitis C. Am J Gastroenterol. 1998;93:2452-2456.

6. Chu CW, Hwang SJ, Luo JC, et al. Clinical, virological, and pathological significance of increased serum $\alpha$-fetoprotein levels in patients with chronic hepatitis C. J Clin Gastroenterol. 2001;32:240-244.

7. Taketa K. Alpha-fetoprotein: reevaluation in hepatology. Hepatology. 1990;12:1420-1432.

8. Males S, Gad RR, Esmat G, et al. Serum alpha-foetoprotein level predicts treatment outcome in chronic hepatitis C. Antivir Ther. 2007;12:797-803.

9. Nunez M, Marino A, Miralles C, et al. Baseline serum hepatitis $\mathrm{C}$ virus (HCV) RNA level and response at week 4 are the best predictors of relapse after treatment with pegylated interferon plus ribavirin in $\mathrm{HIV} / \mathrm{HCV}$-coinfected patients. J Acquir Immune Defic Syndr. 2007; 45:439-444

10. Laguno M, Larrousse M, Murillas J, et al. Predictive value of early virologic response in HIV/hepatitis C virus-coinfected patients treated with an interferon-based regimen plus ribavirin. J Acquir Immune Defic Syndr. 2007; 44:174-178.

11. Sterling RK, Lissen E, Clumeck N, et al. Development of a simple noninvasive index to predict significant fibrosis in patients with HIV/HCV coinfection. Hepatology. 2006;43: $1317-1325$.

12. Tong MJ, el-Farra NS, Reikes AR, et al. Clinical outcomes after transfusion-associated hepatitis C. N Engl J Med. 1995;332:14631466. 